\title{
CHARACTERIZATION OF THE CORAL COMMUNITIES \\ AND REEFS OF TWO PREVIOUSLY UNDESCRIBED \\ LOCATIONS IN THE UPWELLING REGION OF GULF OF PAPAGAYO (COSTA RICA)
}

\author{
Carlos Jiménez ${ }^{1 *}$, Giovanni Bassey ${ }^{2}$, Álvaro Segura ${ }^{3}$ and Jorge Cortés ${ }^{1}$
}

\begin{abstract}
In the seasonal upwelling region of Gulf of Papagayo (Northern Pacific coast of Costa Rica), we evaluated and described two previously poorly known coral habitats, Punta Cacique and Bahía Guacamaya. Both localities differed in the extent of the frame-building coral communities and their composition. While Bahía Guacamaya and Punta Cacique had a similar number of coral species (16), live coral cover percent was higher in the coral reefs (ca. 50\% vs. $90 \%$ ) and coral communities (ca. $40 \%$ vs. $50 \%$ ) of the latter. At both localities, branching species (Pocillopora spp.) contributed more as a group to the live coral cover than massive and encrusting corals. Bahía Guacamaya has the largest colonies found so far of two coral species (Pocillopora eydouxi and Pocillopora meandrina) with a limited distribution in Costa Rica. Using long-term records of environmental data, we characterized the seasonality of the upwelling and the dry and rainy seasons that partially explained the low suspension sediment loads and fresh water discharge into Papagayo's coral habitats. The results of our study are important due to the rapid development of the coastal zone of Papagayo and because only a fraction of the littoral has been systematically surveyed. Therefore, we call for more studies that aim to produce baseline data of coral habitats in the area.
\end{abstract}

Keywords: Coral reef, coral cover, upwelling, Costa Rica, Papagayo.

\section{RESUMEN}

En la región de afloramiento estacional del Golfo de Papagayo (Costa Rica), se evaluaron dos ambientes coralinos que nunca antes habían sido estudiados: Punta Cacique y Bahía Guacamaya. En ambas localidades, la extensión y la composición de las comunidades coralinas constructoras de la estructura arrecifal fueron diferentes. En tanto que el número de especies coralinas (16) fue similar en ambas localidades, el porcentaje de cobertura de coral vivo fue mayor en los arrecifes (aproximamente $50 \%$ vs. $90 \%$ ) y las comunidades (aproximadamente $40 \%$ vs. 50\%) coralinas de Punta Cacique. En ambos sitios, las especies de corales ramificados (Pocillopora spp.) como grupo contribuyeron más a la cobertura de coral vivo que otras formas (masivas e incrustantes). La Bahía Guacamaya tiene las colonias más grandes encontradas hasta el momento en Costa Rica de dos especies de distribución limitada (Pocillopora eydouxi y Pocillopora meandrina). Se utilizaron series temporales extensas de datos ambientales para caracterizar la estacionalidad del afloramiento y la estación seca y la lluviosa. Estos dos factores explican parcialmente la poca sedimentación y descarga de agua dulce en los ambientes coralinos de Papagayo. Los resultados de nuestro estudio son importantes, dado que apenas una pequeña fracción de la costa de Papagayo ha sido estudiada sistemáticamente, a pesar del rápido desarrollo costero que ocurre en el área. Por lo tanto, resaltamos la necesidad de realizar más estudios, con el fin de obtener datos de línea base de los ambientes coralinos del área.

Palabras claves: Arrecife coralino, cobertura coral, afloramiento, Costa Rica, Papagayo.

1 Centro de Investigación en Ciencias del Mar y Limnología (CIMAR), Universidad de Costa Rica, San Pedro, $11501-$ 2060, San José, Costa Rica. carlos.jimenez@zmt-bremen.de*

2 Programa de Maestría en Ciencias Marinas y Costeras, Universidad Nacional, Heredia, Apdo. 36-3000, Heredia, Costa Rica.

3 World Wildlife Fund., Apdo. 629-2350, San Francisco de Dos Ríos, San José, Costa Rica.

Recibido 27-III-2010

Aceptado 24-VI-2010

DOI: http://dx.doi.org/10.15359/revmar.2.8 


\section{INTRODUCTION}

Until relatively recently, the environmental conditions in the three major wind-induced upwelling regions of the eastern Pacific, namely in the gulfs of Tehuantepec (Mexico), Papagayo (Costa Rica) and Panama, were considered detrimental to reef corals and not conducive to construction of reef frameworks (Dana, 1975). This perception has changed as new coral habitats within the upwelling areas in Costa Rica and Panama have been described and systematically investigated (Cortés, 2003). However, during extremely strong upwelling, under the combined effect of low sea water temperature, eutrophication, algal overgrowth, and bioerosion, corals can be killed, and live coral cover reduced (Jiménez, 2001a; Bednarsky \& Morales-Ramírez, 2005; Glynn et al. 2007). A series of such extreme upwelling events may have taken place during the Little Ice Age $\left(15^{\text {th }}\right.$ to $19^{\text {th }}$ Centuries A.D.), when sea water temperature in the tropics decreased $2-3^{\circ} \mathrm{C}$ (Winter et al. 2000) and it may have been responsible for the death of a large track (ca. $100 \mathrm{~km}$ ) of corals in Gulf of Papagayo (hereinafter Papagayo) (Glynn et al. $1983)$ and other parts of the Pacific coast of Costa Rica (Jiménez, 2002).

Located at the northern Pacific coast of Costa Rica, Papagayo has generated special interest due to the high abundance of coral habitats supporting communities of several levels of complexity and with rare or endangered coral species of very restricted distributions (Cortés \& Murillo, 1985; Cortés \& Jiménez, 2003; Cortés \& Wehrtmann, 2009; Jiménez, in prep). For example, Papagayo is the only known place in Central America where a healthy population of the solitary, free-living coral
Fungia (Cycloseris) curvata has been found (Jiménez, 1998, 2001b), and it is also the only place in the eastern Pacific where Leptoseris papyracea, another species of extremely restricted distribution, has been found initiating a reef build up (Jiménez, 1998; Cortés \& Jiménez, 2003). Additionally, it has large monospecific reefs built almost entirely by Pavona clavus, Pocillopora spp., and Gardineroseris planulata (Cortés \& Jiménez, 2003).

The influence of different levels of environmental variability (diel, event, and seasonal) that may have profound impacts on the biota in the upwelling zone (e.g. Jiménez, 1998, 2001a), makes Papagayo, and upwelling areas in general (e.g. Reyes-Bonilla, 2001; Riegl \& Piller, 2003), an interesting natural laboratory to study and test coral responses to local (e.g. development) and global changes (e.g. sea's acidification). However, Papagayo is one of the epicenters of coastal development in Costa Rica, and rapid construction of infrastructure is happening without an appropriate evaluation of its effects on the coastal marine ecosystems in the area. Indeed, it is necessary that resource managers, decision makers, and developers have basic ecological information to design and to comply with strategies to mitigate damage from construction and land transformation (Lester et al. 2009). It must be part of the governmental agenda to know the composition of the marine habitats, their distribution and health condition, in order to make decisions or take management actions so that development is not a threat.

Here, we report and characterize the coral habitats of Punta Cacique and Bahía Guacamaya, Gulf of Papagayo, that sustain numerous and previously undescribed coral habitats, with the purpose of providing baseline data needed to develop management strategies in the coastal zone of Costa Rica. 


\section{MATERIAL AND METHODS}

\section{Study sites}

This study focuses on the coral reefs and communities of two localities in the Gulf of Papagayo (hereafter Papagayo, Costa Rica): Punta Cacique $\left(10.3^{\circ} \mathrm{N}\right.$, $\left.85.4^{\circ} \mathrm{W}\right)$ and Bahía Guacamaya $\left(10.3^{\circ}\right.$ N, $85.4^{\circ} \mathrm{W}$ ) (Fig. 1). Previously, the coral communities and reefs of Punta Cacique (hereafter Cacique) were systematically surveyed only at its NW and NE littoral inside Bahía Hermosa (Fig. 1A) (Jiménez, 1997，1998，2001b). These coral areas are in shallow $(<12 \mathrm{~m})$ waters and sheltered from the prevailing trade winds (N-NE) during the dry season (see below). Due to the geomorphology of the coast, only occasionally these communities are affected by strong S-SW swells, common during the rainy season (Jiménez, 1998, 2001a). The southern littoral of Cacique has no major beaches, and it is mainly formed by small high-angle basaltic cliffs. The most populous center in the area (Playas del Coco) is located $1 \mathrm{~km}$ away. Therefore, visitation and extraction of corals and other organisms are regular activities at Cacique.

Bahía Guacamaya (hereafter Guacamaya) is also a well protected bay, surrounded by several hundred meters-high hills, and with an irregular shoreline composed of sandy beaches, basaltic rocky shores, and two small estuaries with mangroves. Guacamaya was never surveyed before this study. Corals are found all the way down to $15 \mathrm{~m}$, dispersed along the rocky shore, in exposed or submerged banks and around a small islet. There is an incipient reef development in the cove facing the islet (site 18, Fig.1B) and a well developed shallow patch reef in a small bay known as Guacamayita (sites 10-11, Fig. 1B). Although there are no major human settlements in Guacamaya and vicinities, visitation to the area originates from sizable coastal towns (e.g. Playas del Coco, $12 \mathrm{~km}$ away), mostly for recreational diving and fishing, and for commercial extractive activities (aquarium-trade and
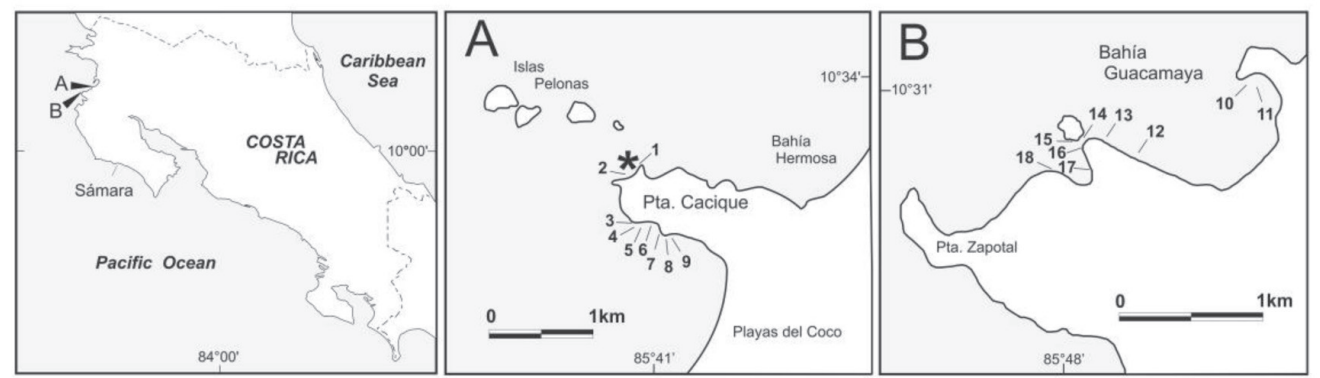

Fig. 1. Location of the study sites Cacique (A) and Guacamaya (B) at the northern Pacific coast of Costa Rica (Golfo de Papagayo). Sites are numbered from north to south and correspond to coral reefs (1-2, 10-11) and coral communities upon basalt or sand substrates (3-9, 12-18). Location of the temperature data logger $(*)$

Fig. 1. Ubicación en la zona estudiada, Cacique (A) y Guacamaya (B) en la costa norte del Pacífico de Costa Rica (Golfo de Papagayo). Los sitios son numerados de norte a sur y corresponden a los arrecifes de coral $(1-2,10-11)$ y las comunidades de coral en sustratos basálticos o arenosos (3-9, 12-18). Ubicación en el registrador de datos de temperatura $(*)$ 
net fishing). There are near-future plans to urbanize Cacique and Guacamaya and to build marinas and other harbor facilities.

\section{Sea water temperature and meteorological data}

In order to characterize the seasonal variability (rainy and dry seasons and the upwelling) of the environment at the study sites, subsurface sea water temperature (SWT), sea surface temperature (SST), rainfall and sun hours were analyzed. One Stow-Away (Onset Computer Inc.) underwater temperature data logger $( \pm$ $0.5^{\circ} \mathrm{C}$ accuracy) was deployed at $5 \mathrm{~m}$ depth in Cacique (Fig. 1A). The thermistor (set to record every $36 \mathrm{~min}$ ) was positioned among Pocillopora spp. colonies from May 1998 to November 2006. Long-term SST data is a monthly averaged global gridded analysis of SST $\left(1^{\circ} \times 1^{\circ}\right.$ grid centered on $10.5^{\circ} \mathrm{N}$, $86.5^{\circ} \mathrm{W}$ ) from the Reynolds NCEP optimal interpolation analysis (Reynolds \& Smith, 1994). This data set is a blend of in situ observations and bias-corrected satellite data. Rainfall and sunshine-hours data from the meteorological station nearest to the study area (Liberia airport) were provided by the Costa Rican Instituto Meteorológico Nacional. The seasonality of these two variables, that is, their monthly contribution to the annual cycle, is expressed as monthly percentages of annual totals, which were calculated by averaging monthly means derived for the period 1957-2009 (rain) and 1976-2009 (sunshine-hours).

\section{Cover transects}

Surveys to quantify the percentage of cover of four benthic categories (live and dead corals, coral species, macroalgae and free substrate) were undertaken during the second and first half of 2006 and 2007, respectively. Although we surveyed the en- tire southern flank of Cacique, we chose the largest coral communities which were found around a small cove in the south (Fig. 1A) as our main study sites. Additionally, two previously known reefs (1-2, Fig. 1A) were included in the survey in order to assist in the comparison of Cacique with Guacamaya. Sites in Guacamaya were located at the N and NW ends of the bay and at the islet close to the shore (Fig. 1B). Percentage of cover was determined by means of a $10 \mathrm{~m}$ long chain $(1.1 \mathrm{~cm}$ link $^{-1}$ ) along four transects interspersed every five meters (2-9 $\mathrm{m}$ depth range) parallel to the shore line and across 18 different sites (Table 1). Percentages were calculated by translating the number of links corresponding to each category of substrate into a percent with respect to the transect's total number of links (i.e. absolute cover). For analytical comparisons, data was separated into two groups following a structural criterion: (1) coral reefs, if there was a frame-constructing coral community upon which coral colonies grew, and (2) coral communities, if the colonies were established upon basaltic or sandy substrate. Statistical comparisons utilizing the number of links, not the percentages (McManus, 1993), were performed after testing for normality and heterogeneity of variances (Cochran test). When non-normality and heterogeneity of variances were significant $(P<0.05)$, the square root or $\log (\mathrm{x}+1)$ transformation was applied. Comparisons between localities of the mean percentage of cover for each coral species, grouped by structural criterion (coral reefs, coral communities), were performed using analysis of variances (ANOVA) and the differing pairs identified with a post hoc test (Tukey, $P<0.05$ ). Similar approach was used to identify differences between sites grouped by substrate 
Table 1. Description of the sampling sites at the two surveyed localities. Total number of transects (n) in parenthesis. Turbulence according to exposure (e.g. leeward, windward, incoming S-SW swells). Sites numbered from north to south according to figure 1 Cuadro 1. Descripción de los sitios de muestreo en las dos localidades muestreadas. Número total de transectos (n) entre paréntesis. La turbulencia de acuerdo con la exposición (por ejemplo, sotavento, barlovento, entrada S-SW). Sitios numerados de norte a sur, según la figura 1

\begin{tabular}{ccccc}
\hline Locality & Site & Depth range (m) & $\begin{array}{c}\text { Predominant } \\
\text { Substrate }\end{array}$ & $\begin{array}{c}\text { Degree of } \\
\text { Turbulence }\end{array}$ \\
\hline Cacique $(\mathrm{n}=36)$ & 1 & $3-8$ & Coral & Medium \\
& 2 & $2-9$ & Coral & Medium \\
3 & $3-9$ & Basalt & Medium \\
& 4 & $2-9$ & Basalt-Sand & Medium \\
& 5 & $2-9$ & Basalt & Low \\
& 6 & $3-9$ & Basalt-Sand & Low \\
& 7 & $2-8$ & Sand-Basalt & Medium \\
& 8 & $2-8$ & Basalt-Sand & High \\
& 9 & $3-9$ & Basalt-Sand & High \\
\hline Guacamaya $(\mathrm{n}=36)$ & 10 & $2-8$ & Coral-Dead coral & Medium \\
& 11 & $2-8$ & Coral-Dead coral & Medium \\
& 12 & $3-8$ & Basalt-Sand & Medium \\
& 13 & $3-9$ & Basalt & Medium \\
& 14 & $4-9$ & Basalt & High \\
& 15 & $3-8$ & Basalt & High \\
& 16 & $3-8$ & Basalt & Medium \\
& 17 & $3-6$ & Basalt-Sand & Low \\
& 18 & $3-9$ & Basalt-Dead & Low \\
& & & coral-Sand & \\
\hline
\end{tabular}

category and structural criterion. Student's $t$-test was used to compare the total cover (all sites pooled) between localities ( $\mathrm{Ca}$ cique vs. Guacamaya) sorted by substrate category and structural criterion.

\section{RESULTS}

\section{Sea water temperature and meteorological data}

Mean monthly SWT and SST and monthly percentage of annual totals of meteorological data are presented in Fig. 2. The long-term records show a strong seasonality which can be used to define a noticeable dry and sunny season (Fig. 2A), which, on average, starts in November and extends to April, and rainy and overcast conditions which prevail during the rest of the year (rainy season), except for a short mid-year dry period known as "Veranillo de San Juan". Water temperature follows this pattern (Fig. 2B) where the lowest temperatures occur between February and March of each year, and highest tempera- 
A.

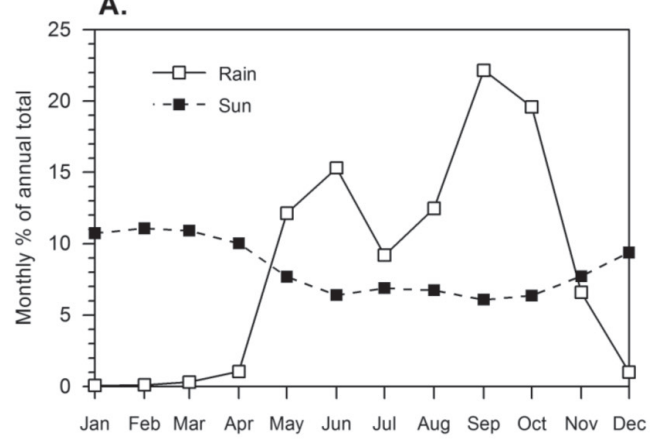

B.

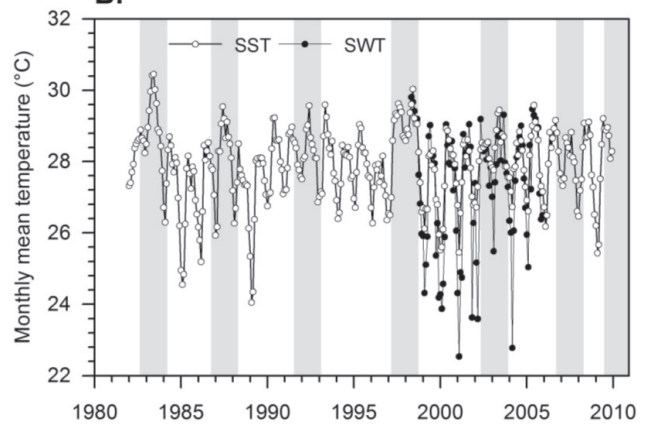

Fig. 2. Long-term environmental data for the Gulf of Papagayo area. Mean monthly percentages of annual totals of rainfall and sunshine hours (A). In situ (5 m depth, SWT) and satellite-derived (surface, SST) sea water temperature (B). Vertical gray bars indicate periods of coral bleaching coincidental with El Niño events

Fig. 2. Datos ambientales a largo plazo para el área del Golfo de Papagayo. La media mensual de los porcentajes de los totales anuales de precipitación y horas de sol (A). In situ (5 m de profundidad, SWT) y procedentes de los satélites (superficie, SST), la temperatura del agua del mar (B). Las barras verticales grises indican los períodos de blanqueamiento de coral que coinciden con los eventos de El Niño

tures during the second half of the year. Low-temperature months co-occur with the driest and sunniest periods of the year, and with episodic NE trade winds that define the extent of the upwelling season. Variations in the intensity of the upwelling are evident on the SST record during which several warming events associated with the El Niño-Southern Oscillation (ENSO) are manifest, most noticeable being the 1982/83 and 1997/98 events. In general, mild and strong El Niño events are conducive to extensive coral bleaching and mortality in the area (e.g. Jimenez et al. 2001).

Although in situ SWT record follows the same seasonal pattern shown by the SST record, there are spikes of high and low temperature values which are entirely missed in the satellite-derived data. However, the latter is an extremely useful tool to characterize and identify the occurrence of anomalous periods of low or high water temperature.

\section{Cover transects}

Coverage of live (LCC) and dead (DCC) corals together with macroalgae (MC) and free substrate (FSC) were scrutinized in relation to species, study sites, and coral environment (coral reef or coral community). In the transects, a total of fifteen, sixteen coral species were found (Fig. 3). Other species were found during the exploration surveys. For example, the ahermatypic Tubastrea coccinea and Oulangia bradleyi, and the octocorals Muricea cf. californica and Pacifigorgia sp. were found outside of the transects and also at the banks in the vicinity of Guacamaya, such as the popular diving site Bajo Tiburones (Cortés and Jiménez, 2003). The number of species in the transects was almost the same in Cacique and Guacamaya (Gardineroseris planulata was only found at Guacamaya). However, it varied 


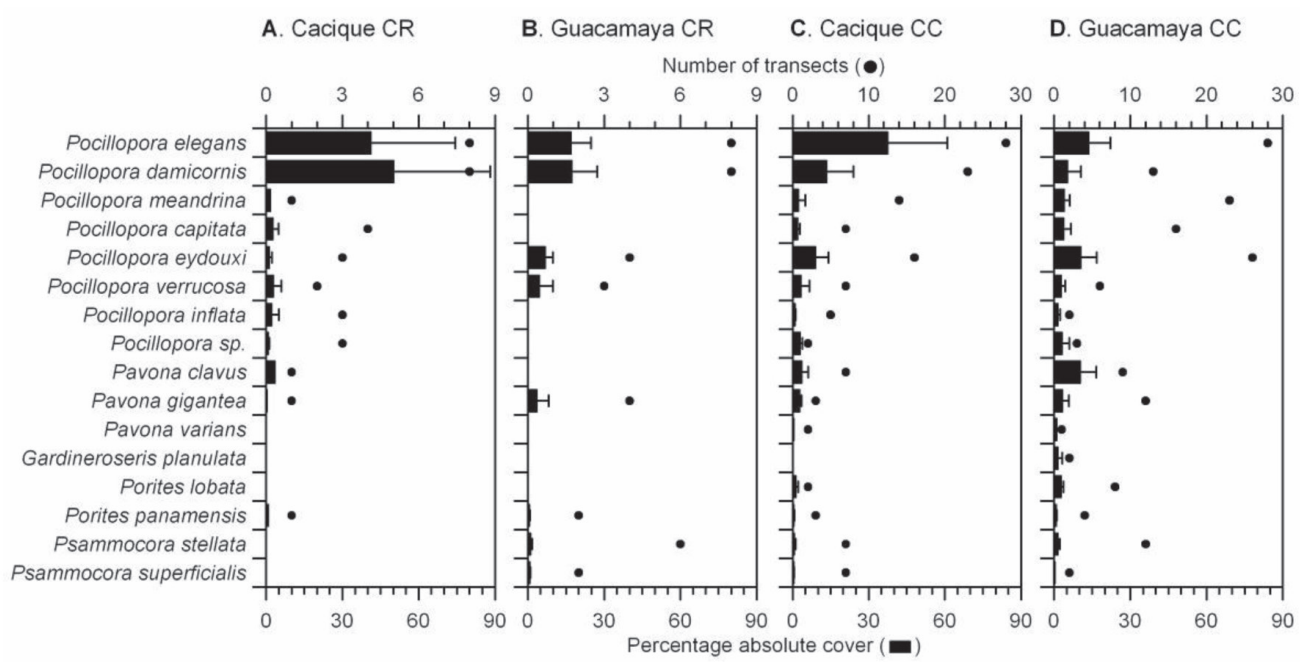

Fig. 3. Mean percentage ( $+1 \mathrm{SD})$ of absolute coral cover (bars) and number of transects (circles) of coral species in the reefs $(\mathrm{A}, \mathrm{B})$ and communities $(\mathrm{C}, \mathrm{D})$ of Cacique and Guacamaya. $\mathrm{CR}=$ coral reefs, $\mathrm{CC}=$ coral communities. Note that number of transects axes have different scales

Fig. 3. El porcentaje promedio $(+1 \mathrm{DE})$ de la cobertura absoluta de coral (barras) y el número de transectos (círculos) de las especies de coral en los arrecifes (A, B) y las comunidades (C, D) de Cacique y Guacamaya. $\mathrm{CR}=$ arrecifes de coral, $\mathrm{CC}=$ comunidades de coral. Tenga en cuenta que las escalas en los ejes transectos son distintas

between coral environments; at Cacique, the coral reefs had more (11 vs. 8) and the coral communities less (15 vs. 17) species than at Guacamaya.

Coverage of macroalgae was mainly of Caulerpa sertularioides mats, which were present in almost all transects and observed widespread down to $14 \mathrm{~m}$ deep. Outside of transects, many free-living coralline algae (rhodoliths) were found at the bottom of the small cove at Guacamaya (sites 1618, Fig. 1B). Scattered in the rhodolith beds (Lithotamnium sp. and Lithophyllum sp.) coral colonies (P. damicornis and Pavona varians) and small aggregations of sea urchins (Astropyga pulminata and Toxopneustes roseus) were observed.

The branching Pocillopora spp. corals contributed more as a group to the LCC than any other species, in particular $P$. elegans, P. damicornis and P. eydouxi (Fig.
3). When comparing between localities the percent of absolute coral cover of the six species that co-occur in the coral reefs of Cacique and Guacamaya $(F=19.9, P<$ 0.0001) (Fig. 3A, B), only P. damicornis had a higher mean cover at the former (50\% vs. 17\%).

In contrast, percent of absolute coral cover of each species in coral communities (Fig. 3 C, D) showed a high variation between localities $(F=54.3, P<0.0001)$. Two species had a significantly higher cover at Cacique than at Guacamaya, those being $P$. elegans (37\% vs. 13\%) and P. damicornis (13\% vs. 5\%). The percent cover of only one species, P. eydouxi $(37 \%$ vs. $13 \%$ ) was higher in the coral communities of Guacamaya than at Cacique.

Noteworthy is the size of $P$. eydouxi and $P$. meandrina colonies found at Guacamaya. At this location, colonies of $P$. 

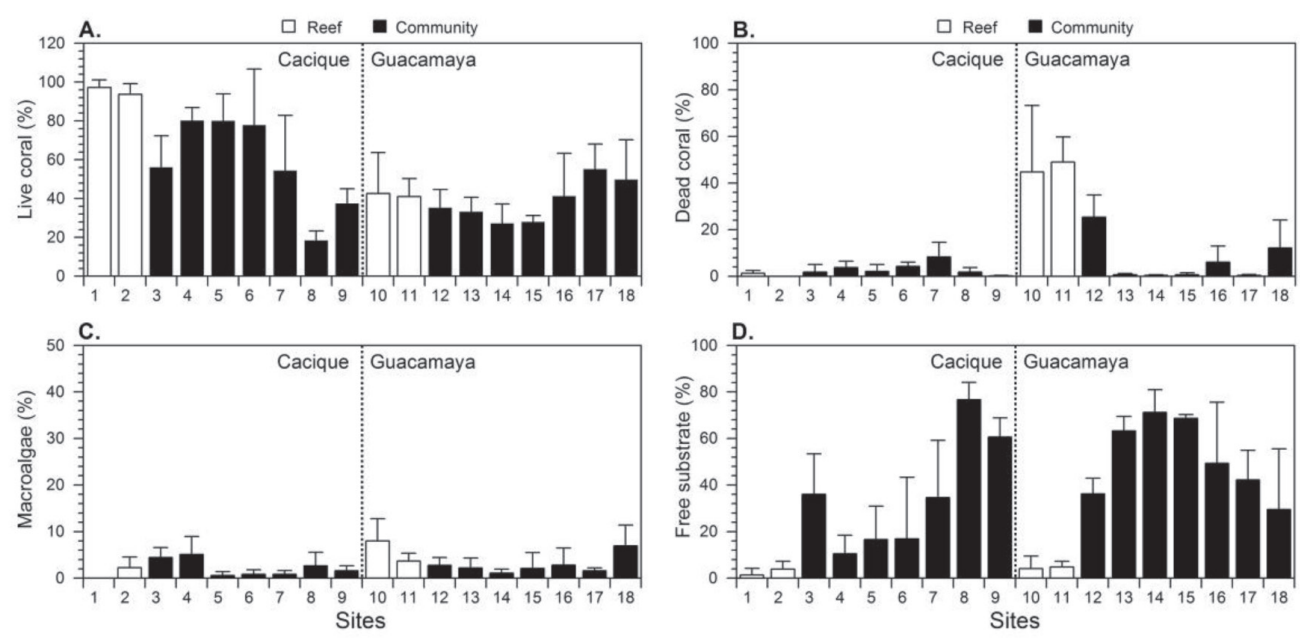

Fig. 4. Cover mean percentage (+1 SD) (bars) of four categories of substrate distributed by site in Cacique and Guacamaya. It is indicated by open and closed bars of the coral reefs and coral communities, respectively. Note that $y$-axes are not on the same scale. See figure1 for location of the sites

Fig. 4. El porcentaje promedio (+1 DE) de la cobertura (barras) de las cuatro categorías de sustrato distribuido por sitio en Cacique y Guacamaya, está indicado por las barras abiertas y cerradas de los arrecifes de coral y comunidades coralinas, respectivamente. Tenga en cuenta que los ejes " $y$ " no están en la misma escala. Ver la figura 1 para la ubicación de los sitios

eydouxi are the largest that we have ever found in Gulf of Papagayo. Thick-branched colonies of about 90x100 cm (max. height $\mathrm{x}$ diameter) were observed at the reef sites (numbers 10-11, Fig. 1B) and somehow smaller exemplars, $60 \times 90 \mathrm{~cm}$, at the small cove (17-18, Fig. 1B). Colonies of $P$. meandrina, though smaller than $P$. eydouxi, were still larger $(50 \times 70 \mathrm{~cm})$ than those that are found on average in the area of Cacique and Islas Murciélagos (about 42 $\mathrm{km}$ north). Most of these large colonies are growing on top of old Pocillopora spp. frameworks (1.3 $\mathrm{m}$ max. thickness), and few were attached to basaltic substrates. Several of those colonies were observed to have bundles of monofilament fishing lines tangled in their branches.

Percentages of the four substrate categories within sites at the studied localities seemed highly variable (Fig. 4). However, significant differences were detected in coral communities only for LCC $(F=6.3, P<$ $0.0001)$ and FSC $(F=5.9, P<0.0001)$ at Cacique, and DCC $(F=5.9, P<0.0001)$ at Guacamaya. Coral reef's sites were more homogeneous with respect to each other $(P$ $>0.05$ ) for all benthic categories.

Total cover (all sites pooled) by locality and substrate category are presented in Fig. 5. The highest mean LCC (all coral species pooled, Fig. 5A) was found in the coral reefs $(t=7.33, P<0.0001)$ and communities $(t=$ 2.91, $P=0.0052)$ of Cacique, with LCC of about $95 \%$ and $55 \%$, respectively. In Guacamaya, high averages of DCC $(t=10.49, P<$ 0.0001 , ) and macroalgae cover $(t=4.06, P$ $=0.0011$ ), with around $45 \%$ and $6 \%$, respectively (Fig. 5B, C) were found. Free substrate cover was higher $(t=2.62, P=0.0114)$ in the communities at Guacamaya (Fig. 5D). 

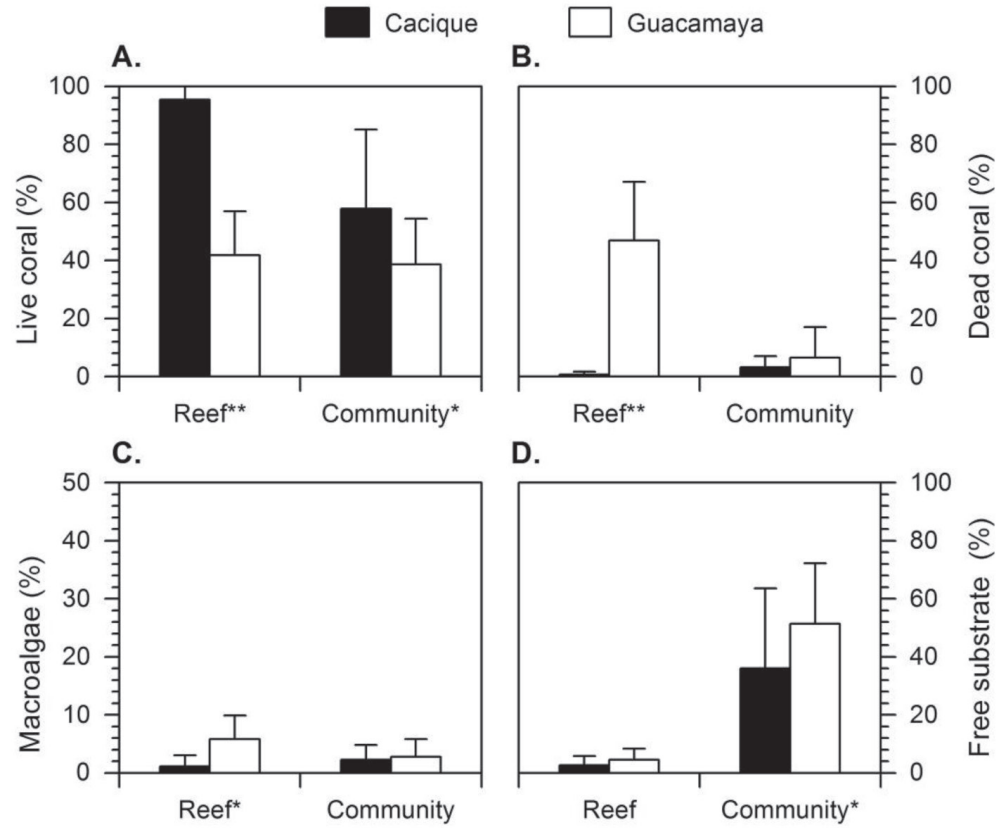

D.

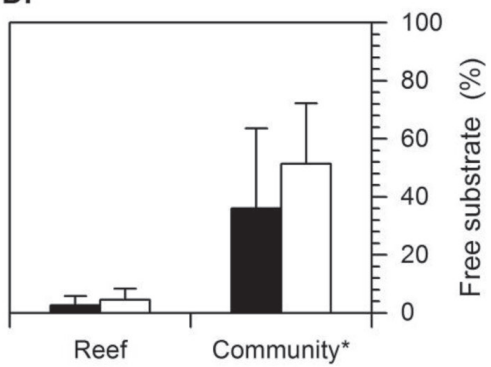

Fig. 5. Cover total percentage ( $+1 \mathrm{SD}$ ) (bars) of four categories of substrate of the coral reefs and coral communities of Cacique and Guacamaya. Note that y-axes are not on the same scale. $t$-test: $* P<0.05 ; * * P<0.001$

Fig. 5. El porcentaje total $(+1 \mathrm{DE})$ de la cubierta (barras) de las cuatro categorías de sustrato de los arrecifes de coral y comunidades coralinas del Cacique y Guacamaya. Tenga en cuenta que los ejes "y" no están en la misma escala. $t$-test: ${ }^{*} P<0.05$; ** $P<0.001$

\section{DISCUSSION}

In this study, we report for the first time on the coral composition of two important reef habitats in the upwelling region of Papagayo. In general, there are substantial gaps in the knowledge of the coastal marine ecosystems in Papagayo and, in particular, the coral reef and community distribution and composition. Based on satellite imagery of SSTs, Jiménez (1998, 2002) suggested that the stretch of coast that is affected by the upwelling of Papagayo extends about $338 \mathrm{~km}$ south of the Nicaraguan border, probably as far as Sámara (Fig. 1). Most of this coast is suitable for the development of coral reefs and communities. However, only a small fraction (about $15 \%$ or $51.1 \mathrm{~km}$ in total) of the littoral has been systematically and qualitatively surveyed. Notwithstanding the small size of the "known" coast, important finds regarding coral and marine-coastal habitats have come to light (reviewed in Cortés \& Jiménez, 2003; Cortés \& Wehrtmann, 2009)

The ecological value of the coral habitats in Cacique and Guacamaya is significant. The southern flank of Cacique was first visited sporadically during 1992-93, when isolated individual small colonies and low live coral cover $(<1 \%)$ were reported (Jiménez, 1998). Since then, growth 
and development of coral communities has been extensive, and numerous corals can be found all the way down to 14 $\mathrm{m}$. At present, there is even an incipient frame construction and abundant, healthy patches of corals in spite of the elevated visitation and extraction of resources. Notwithstanding their small size and the human pressure upon them, these coral communities are without doubt the best in Coco Bay. At the western end of the peninsula, Cacique also has a well developed reef framework, where the high density of pocilloporids results in a tight spatial arrangement, and the colonies grow in juxtaposition, attaining a built up of more than $2 \mathrm{~m}$ in vertical relief, which is the most imposing of the vicinities. At Guacamaya, splendid Pocillopora spp. colonies can be found, the largest reported yet for Papagayo (see below). Additionally, there are three small frame-constructing communities and a much larger reef framework sustaining active coral growth and very large colonies. Furthermore, small communities of rhodoliths were associated with different organisms which increased the diversity of the place, as it is well documented elsewhere (Foster, 2001).

What makes Gulf of Papagayo such a suitable habitat for corals? The high abundance of coral habitats in Papagayo is in stark contrast to other coastal areas in the central and southern Pacific littoral of Costa Rica, where frame-building coral communities are quite restricted or limited in range. Several factors and diagnostic features of a large portion of the southern littoral may explain this trend, which can be generalized to the eastern Pacific region in general (e.g. Denyer \& Cárdenas, 2000; Glynn \& Ault, 2000; Jiménez, 2002). For example, a prolonged and much stronger rainy season (up to $7 \mathrm{~m}$ in some drainage basins), higher run- off and coastal landslides, existence of fresh and brackish water bodies (rivers, estuaries), watersheds enclosed by agricultural lands with increased silt loads and discharge, and long stretches of sandy and high-energy (turbulent) beaches, are all interacting factors that fragment the potentially habitable areas for corals. In consequence, important framework construction and development of large coral reefs and communities are limited to a few favorable areas at the coast and off-shore islands (e.g. Guzmán \& Cortés, 1989, 2001; Cortés, 1990, 1992; Cortés \& Jiménez, 1996, 2003; Jiménez \& Cortés, 2001; Alvarado et al. 2005).

It is well known that sediments and siltation regimes play a major role in controlling coral development. Corals can be directly and indirectly affected by the decrease of availability of light, interference with feeding, abrasion of tissue, and increase of energy expenditure for cleansing, just to mention a few (Cortés \& Risk, 1985; Rogers, 1990; Nugues \& Roberts, 2003; Fabricius, 2005). The low siltation and runoff due to a prolonged dry season partially explain the higher abundance of suitable habitats for corals in the Papagayo area. Our environmental data attest to the dryness of the region. The absence of major rivers discharging sediments and freshwater into the gulf is the fortuitous consequence of a still active tectonic uplifting of the Papagayo's coast (Marshall \& Anderson, 1995). The uplift forces (at least since the Quaternary) the large Tempisque River and other important tributaries to flow along a tiltation axis and away from the gulf's littoral (Montero, 2000). The Tempisque River, with one of the largest drainage basins in the country $\left(>5000 \mathrm{~km}^{2}\right.$, Daniels, 2004), flows parallel to the Gulf of Papagayo at its closest point $(4.8 \mathrm{~km})$, without encountering a topographical gap to discharge into the gulf. However, a plethora of small rivers 
and rivulets of small drainage basins close to shore flow into Papagayo. They are greatly affected by seasonal variations of the rainy periods and also by ENSO events (Waylen $\&$ Laporte, 1999). Some of them are even of an intermittent nature, with active streams only during the rainy months.

In contrast, many rivers in the south have much larger and wider drainage areas (Waylen \& Laporte, 1999; Krishnaswamy et al. 2001a), and their flow is only affected during strong to very strong ENSO events (Waylen \& Laporte, 1999). In consequence, the freshwater and sediment inputs in the south are year-round, changing only with the waning and strengthening of the rainy season and the land use in the watersheds (Krishnaswamy et al. 2001b). In contrast, Gulf of Papagayo provides a relatively sediment-free environment whose physical settings in terms of geomorphology, oceanography and climatology are unique in the country and offers more suitable habitats for corals.

After considering the important ecological value of the coral habitats in Cacique and Guacamaya, and the remarkable and unique physical settings of Gulf of Papagayo, there are some concerns that need to be addressed. For example: Is it important or necessary to produce baseline data of previously unknown coral habitats in the Papagayo area and elsewhere? Studies that will produce baseline data are necessary and urgent, partially due to the fact that the northwestern region of Costa Rica is considered one of the top-most important areas in the country for costal tourism (Raventós, 2006). However, here are important aspects that are not properly addressed, such as mitigation measures, implementation of the maritime and coastal law, and restoration and monitoring of altered coastal ecosystems after the construction. In con- sequence, development of the coastal-zone without an adequate plan would affect the condition of the coral habitats through the increase of sedimentation during the constructional phase (Jiménez, 1997, 1998) and the unavoidable pollution that follows the development of coastal infrastructure (Hinkey \& Zaidi, 2007).

We conclude that is critically important to describe and study in detail the coral habitats of this and any other region, taking into account their distribution, extent, composition, condition and diversity (Bellwood \& Hughes, 2001, Guzmán et al. 2004). This needs to be done before Papagayo's coastal marine ecosystems deteriorate to a point that the research will be no more than forensics.

\section{ACKNOWLEDGEMENTS}

The research was partially supported by the Vicerrectoría de Investigación, Universidad de Costa Rica (projects 80896-601 and 808-98-013), the research programs of the Áreas de Conservación Guanacaste (ACG) and Tempisque (ACT), and Conservation International (project CI-UCR FUNDEVI-2059). We acknowledge the help in the field of M.M. Chavarría (ACG), M. Méndez (ACT), M. Lara and D. Barrera. Two anonymous reviewers made thoughtful comments that greatly improved the manuscript.

\section{BIBLIOGRAPHY}

Alvarado, J. J., Cortés, J., Fernández, C. \& Nivia, J. (2005). Coral communities and reefs of Ballena Marine National Park, Pacific coast of Costa Rica. Cienc. Mar., 31, 641-651.

Bednarsky, M. \& Morales-Ramírez, A. (2005). Composition, abundance and 
distribution of macrozooplankton in Culebra Bay, Gulf of Papagayo, Pacific coast of Costa Rica and its value as bioindicator of pollution. Rev. Biol. Trop., 52 (2), 105-119.

Bellwood, D. R. \& Hughes, T. P. (2001). Regional-scale assembly rules and biodiversity of coral reefs. Science, 292, 1532-1534.

Cortés, J. (1990). The coral reefs of Golfo Dulce, Costa Rica: distribution and community structure. Atoll. Res. Bull., 344, 1-37.

Cortés, J. (1992). Los arrecifes coralinos de Golfo Dulce, Costa Rica: aspectos ecológicos. Rev. Biol. Trop., 40, 19-26.

Cortés, J. (2003). Coral reefs of the Americas: An introduction to Latin American Cotal Reefs. En J. Cortés (Ed.), Latin American Coral Reefs (pp. 1-7). Amsterdam: Elsevier Science B.V.

Cortés, J. \& Jiménez, C. (1996). Coastal marine environments of Parque Nacional Corcovado, Puntarenas, Costa Rica. Rev. Biol. Trop., 44 (3), 35-40.

Cortés, J. \& Jiménez, C. (2003). Corals and coral reefs of the Pacific of Costa Rica: history, research and status. En J. Cortés (Ed.), Latin American Coral Reefs (pp. 361-385). Amsterdam: Elsevier Science B.V.

Cortés, J. \& Murillo, M. M. (1985). Comunidades coralinas y arrecifes del Pacífico de Costa Rica. Rev. Biol. Trop., 33, 197-202.

Cortés, J. \& Risk, M. J. (1985). A reef under siltation stress: Cahuita, Costa Rica. Bull. Mar. Sci., 36, 339-356.

Cortés, J. \& Wehrtmann, I. S. (2009). Diversity of marine habitats of the Caribbean and Pacific of Costa Rica. En I. S. Wehrtmann \& J. Cortés (Eds.), Marine Biodiversity of Cos- ta Rica, Central America (pp. 1-45). Berlin: Springer.

Dana, T. F. (1975). Development of contemporary eastern Pacific coral reefs. Mar. Biol., 33, 255-374.

Daniels, A. (2004). Protected area management in the watershed context: a case study of Palo Verde National Park, Costa Rica. Thesis M.Sc. Unpublished. University of Florida, Gainsville, Florida.

Denyer, P. \& Cárdenas, G. (2000). Costas marinas. En P. Denyer \& S. Kussmaul (Eds.), Geología de Costa Rica (pp. 185-218). Costa Rica: Instituto Tecnológico de Costa Rica.

Fabricius, K. E. (2005). Effects of terrestrial runoff on the ecology of corals and coral reefs: review and synthesis. Mar. Poll. Bull., 50, 125-146.

Foster, M. (2001). Rhodoliths: between rocks and soft places. J. Phycol., 37, 659-667.

Glynn, P. W. \& Ault, J. S. (2000). A biogeographic analysis and review of the far eastern Pacific coral reef region. Coral Reefs, 19, 1-23.

Glynn, P. W., Druffel, E. \& Dunbar, R. (1983). A dead Central American coral reef tract: possible link with the Little Ice Age. J. Mar. Res., 41, 605-637.

Glynn, P. W., Wellington, G. M., Riegl, B., Olson, D. B., Borneman, E. \& Wieters, E. A. (2007). Diversity and biogeography of the Scleractinian coral fauna of Easter Island (Rapa Nui). Pac. Sci., 61, 67-90.

Guzmán, H. M. \& Cortés, J. (1989). Coral reef community structure at Caño Island, Pacific Costa Rica. Mar. Ecol., 10, 23-41.

Guzmán, H. M. \& Cortés, J. (2001). Changes in reef community structure after fifteen years of natural distur- 
bances in the eastern Pacific (Costa Rica). Bull. Mar. Sci., 69, 133-149.

Guzmán, H. M., Guevara, C. A. \& Breedy, O. (2004). Distribution, diversity, and conservation of coral reefs and coral communities in the largest marine protected area of Pacific Panama (Coiba Island). Environm. Conserv., 31, 111121.

Hinkey, L. M. \& Zaidi, B. R. (2007). Differences in SEM-AVS and ERMERL predictions of sediment impacts from metals in two US Virgin Islands marinas. Mar. Poll. Bull., 54, 180-185.

Jiménez, C. (1997). Corals and coral reefs of Culebra Bay, Costa Rica: anarchy at the reef. Proceedings of the 8th International Coral Reef Symposium. Panamá

Jiménez, C. (1998). Arrecifes y comunidades coralinas de Bahía Culebra, Pacífico Norte de Costa Rica (Golfo de Papagayo). Tesis de Maestría no publicada. Universidad de Costa Rica.

Jiménez, C. (2001a). Seawater temperature measured at the surface and at two depths (7 and $14 \mathrm{~m}$ ) in one coral reef at Culebra Bay, Gulf of Papagayo, Costa Rica. Rev. Biol. Trop., 49 (2), 153-161.

Jiménez, C. (2001b). Arrecifes y ambientes coralinos de Bahía Culebra, Pacífico de Costa Rica: aspectos biológicos, económico-recreativos y de manejo. Rev. Biol. Trop., 49 (2), 215-231.

Jiménez, C. (2002). Effects of recent warming events on coral reef communities of Costa Rica (Central America). $\mathrm{PhD}$ dissertation, University of Bremen, Germany. 169 pp. Available at http://elib.suub.uni-bremen.de

Jiménez, C. \& Cortés, J. (2001). Effects of the 1991-92 El Niño on scleractinian corals of the Costa Rican central Pacific coast. Rev. Biol. Trop., 49 (2), 239-250.
Jiménez, C., Cortés, J., León, A. \& Ruiz, E. (2001). Coral bleaching and mortality associated with the 1997-1998 El Niño event in an upwelling environment at the eastern Pacific (Gulf of Papagayo, Costa Rica). Bull. Mar. Sci., 68, 151169.

Krishnaswamy, J., Richter, D., Halpin, P. N. \& Hofmockel, M. S. (2001a). Spatial patterns of suspended sediment yields in a humid tropical watershed in Costa Rica. Hydrol. Process., 15, 2237-2257.

Krishnaswamy, J., Halpin, P. N. \& Richter, D. (2001b). Dynamics of sediments discharge in relation to land-use and hydro-climatology in a humid tropical watershed in Costa Rica. J. Hydrology, 253, 91-109.

Lester, S. E., Halpern, B. S., Grorud-Colvert, K., Lubchenco, J. B., Ruttenberg, I., Gaines, S. D., Airamé, S. \& Warner, R. R. (2009). Biological effects within notake marine reserves: A global synthesis. Mar. Ecol. Prog. Ser., 384, 33-46.

Marshall, J. \& Anderson, R. (1995). Quaternary uplift and seismic cycle deformation, Península de Nicoya, Costa Rica. Geol. Soc. Amer. Bull., 107, 463-473.

McManus, J. W. 1993. Problems with percent composition analyses. Reef Encounter, 13, 9-10.

Montero, W. (2000). Sismología y geotectónica. En P. Denyer \& S. Kussmaul (Eds.), Geología de Costa Rica (pp. 219-239). Costa Rica: Instituto Tecnológico de Costa Rica.

Nugues, M. M. \& Roberts, C. (2003). Partial mortality in massive reef corals as an indicator of sediment stress on coral reefs. Mar. Poll. Bull., 46, 314-323.

Raventós, P. (2006). The internet strategy of the Costa Rican Tourism Board. $J$. Bussiness Res., 59, 375-386. 
Reyes-Bonilla, H. (2001). Effects of the 1997-1998 El Niño-Southern Oscillation on coral communities of the Gulf of California, México. Bull. Mar. Sci., 69, 251-266.

Reynolds, K. W. \& Smith, T. M. (1994). Improved global sea surface temperature analyses. J. Clim., 7, 929-948.

Riegl, B. \& Piller, W. (2003). Possible refugia for reefs in times of environmental stress. Int. J. Earth Sci., 92, 520-531.
Rogers, C. S. (1990). Responses to coral reefs and reef organisms to sedimentation. Mar. Ecol. Prog. Ser., 62, 185-202. Waylen, P. \& Laporte, M. S. (1999). Flooding and the El Niño-Southern Oscillation phenomenon along the Pacific coast of Costa Rica. Hydrol. Process., 13, 2623-2638.

Winter, A., Ishioroshi, H., Watanabe, T., Oba, T. \& Christy, J. (2000). Caribbean Sea surface temperatures: Two-tothree degrees cooler than present during the Little Ice Age. Geophys. Res. Lett., 27, 3365-3368. 